\title{
"Economic development" and gender equality: explaining variations in the gender poverty gap after socialism
}

When we look at the whole world - or at least as many data points as are available to the industrious researcher- evidence points to a positive association between the level of economic development and various aspects of gender equality. As economic growth progressed in the past centuries the gender gap in educational attainment, labor force participation and mortality has declined (Charles 2011; Dorius and Firebaugh 2010), women's access to positions of political power increased (Moore and Shackman 1996) and women's overall well-being, measured by the composite GDI or GEM indices, improved (Forsythe et al 2000).

There are reasons, however, to be doubtful about the promise of economic development for women's emancipation. Researchers have noted rising gender inequality in countries subjected to structural adjustment and global market integration and have argued that these processes often results in a devaluation of women's skills, gender discrimination in employment, the increasing vulnerability of workers in a labor market dominated by profit hungry transnational capitalists, as well as the contamination of natural resources used for subsistence by poor households (Boserup 1970; Nash and Fernandez-Kelly 1983; Shittirak 1988; Tinker 1990, Ward 1993).

These arguments rely heavily on research conducted in developing Latin American, Asian and African countries, where prior to the introduction of structural adjustment policies (SAP's) women's level of education and experience in the formal labor market had been significantly inferior to those of men and thus their vulnerability to patriarchal subjugation had been especially pronounced. Post-socialist societies in 
Central and Eastern Europe (CEE) provide a different arena to test and reformulate theories about the relationship between modern day "economic development" and gender inequality.

In this article we use the term "economic development" to refer to a change in the volume of GDP achieved through the application of structural adjustment policies. SAP's are a type of development policy, inspired by the neoliberal economic model of the Washington consensus and employed extensively in the countries of the global South (Beneria 1999). They typically include capital and labor market deregulation, currency devaluation, trade and financial liberalization, the encouragement of global market integration, as well as, importantly, austerity in state spending. We use "economic development" as shorthand to indicate both these policies and their intended consequences for GDP growth because the two seem difficult to disentangle: they simultaneously appear as goals to be attained and instruments to be used in the development discourse of international policy institutions.

CEE countries followed different varieties of the structural adjustment path towards global market integration but they started this process with a fully trained, highly experienced, primarily urban female labor force, low levels of fertility, absolute poverty and class inequality as well as a lengthy history of state provided welfare. We thus ask the following two questions. First, in this context, what is the impact of "economic development" on gender inequality in poverty? Second, what aspect of this process is likely to affect the gender poverty gap the most and what does this suggest about the emerging gender regimes in post-socialist societies? 
A sharp decline in the volume of production and employment levels followed the collapse of the state socialist regimes in Eastern Europe and the Soviet Union in the early 1990s. Class, race and gender inequalities visibly deepened everywhere, although to different degrees (Bandelj and Mahutga 2010; Pascall and Kwak 2005; Szelenyi and Ladanyi 2006). In 2008, poverty rates ${ }^{1}$ in the newly minted capitalist economies were, on average, higher than those found in more developed continental European Union member states and varied between 9\% (in the Czech Republic) and 34\% (in Latvia, see Table 1, column 6). The gender poverty gap, i.e. the proportion of men's poverty rate to that of women's, ranged from women's slight relative advantage (in Hungary and Poland) to large gender gaps indicating women's increased vulnerability (in the Czech Republic and Bulgaria, see table 1, column 4).

In this article we begin to explain this cross-country variation in the gender poverty gap and contribute to the rapidly growing literature on the local correlates of global gender inequality. Unlike in previous studies our goal is not merely to assess whether or not women disproportionately bear the burden of the post-socialist transition (Einhorn 1993; Fodor 1997; Ghodsee 2005; Glass 2008). Rather we explore some of the macro-economic and institutional factors, which shape the level of gender inequality in post-socialist countries and identify the conditions under which women fare better or worse relative to men during and after global market integration. In the process we

\footnotetext{
${ }^{1}$ Poverty here is defined as per capita equivalized household income below $60 \%$ of the national median, see a more detailed description in the section on research methods below.
} 
characterize the nature of the social and economic transformation itself, of which practices, ideologies and assumptions of gender relations are a constitutive part.

We use the 2008 wave of the European Union's Statistics on Income and Living Conditions (EU-SILC) and a set of multilevel logistic regression models to explore variations across ten Central and East European (CEE) countries in the gender poverty gap. We argue that fast growing, foreign capital- dependent post-socialist economies tend to sustain higher levels of gender inequality in poverty. In addition, we show that the key determinant of the gender poverty gap is the lack of social protection. Although the literature on gender and the welfare states is extensive, the importance of the state and the public sector is under-explored in all but the most recent scholarship on "gender and development." Post-socialist countries in the process of marketization prompt us to integrate these two fields and add the state back into discussions of women's role in “development."

\section{"ECONOMIC DEVELOPMENT" AND THE GENDER POVERTY GAP}

After the disintegration of the state socialist regimes in 1990, productive assets in Central and Eastern European countries were quickly privatized, market exchange replaced state redistribution as the central mechanism for the allocation of resources, prices and wages were liberalized, state spending was cut back and redirected. Foreign capital investment flocked to the region, along with advisors from the International Monetary Fund and the European Union, providing not only capital and loans but also blueprints for the integration of the post-socialist countries into the global economy and for their accession to European Union membership. The IMF underwrote loans with strict conditionalities 
attached, most of which followed the structural adjustment scripts introduced in other areas of the world: they required, among others, closely monitored limits on government spending, increased labor market flexibility, controls on wage growth, financial deregulation and the creation of favorable conditions for foreign capital penetration. While the toolkits were quite similar, each country adopted different aspects and pursued somewhat divergent paths to privatization, liberalization and growth depending on their geo-political and economic position, as well as their industrial structure, political opportunities and debt legacies (Bohle and Greskovits 2012; Drahokoupil 2009; Hamm, King and Stuckler 2012). The similarities among CEE countries help us control for some of the political-historical factors of interest and the differences allow us to identify the impact of a handful of elements of "economic development" on gender inequality in poverty. Specifically we focus on macro-economic policies (FDI investment, financial deregulation) and growth, as well as institutional factors, such as government spending overall and on pensions and family policies in particular.

\section{Macro-economic policies for development: foreign direct investment, financial liberalization and growth}

Foreign direct investment has played a monumental role in reshaping the structure of production in the global South. Transnational factories and corporations, relocating to Latin American, Asian and most recently to Central and East European countries, have created a multitude of work opportunities targeting especially "docile" and "nimble fingered" women (Ong 1987, Mies 1994, Ward 1994). But such employment is often unhealthy, unstable, highly exploitative and may exacerbate rather than eliminate 
capitalist patriarchal subjugation (Enloe 2000, Fernandez- Kelley 1983). Global competition to attract investments has led to a lowering of labor standards and the worsening of the conditions of work: informal jobs, subcontracting, temporary and ad hoc work arrangements have proliferated affecting women disproportionately (Kudva and Beneria 2005). Furthermore, export-oriented production has exacerbated the disruption of village communities and the erosion of the "commons" (Isaksen, Devi and Hochschield 2010), caused migration and displacement in unforeseen proportions (Sassen 2003), and has contributed to an increase in women's work burden and economic and personal vulnerability (Beneria 2003, Mies 1999).

Financial liberalization is a similarly important policy goal of structural adjustment packages. Neo-liberal policy makers claim that state control over financial markets impedes productivity through creating a disincentive for investments, which ultimately stunts economic growth. But the de-regulation of financial markets is potentially quite problematic for gender equality as it may lead to increased volatility, an emphasis on market -based solutions for social problems, and thus more vulnerability for those in a weaker bargaining position, i.e., women (Braunstein 2012, Seguino et al 2009).

Overall, researchers have shown that structural adjustment fueled growth does not necessarily lead to more gender equality in access to credit and decent employment (Beneria 2003, Berik and Rogers 2009), in wages (Seguino 2000, Standing 1999, Braunstein 2012), in participation in political or economic decision making or in improvements in health outcomes (Kabeer 2009). At least in the initial phases of growth researchers have found that women's overall wellbeing declines both in absolute terms and relative to men's (Boseerup 1970, Forsythe 2000). In fact, some evidence suggests 
that rather than simply being its cause, gender inequality in wages has actually fueled economic growth in Latin American economies: women's meager pay has served as an incentive for foreign investors as it allowed them to keep labor costs exceptionally low (Berik, van der Meulen Rodgers and Seguino 2009; Seguino 2000).

On the other hand, it is doubtless that foreign direct investment has created more employment options and especially new opportunities for urban lower skilled women, bringing about a veritable 'feminization of employment' (Mason and King 2001, Tzannatos 1999, Standing 1999). Even if these jobs are typically of rather poor quality they may be considered an improvement over what had been available earlier and women gain a degree of economic independence not experienced before (Lim 1983). Women's wages have increased more than men's in a number of developing countries (Tzannatos 1999, World Bank 2001) and there is some evidence to suggest that micro-credit arrangements were occasionally successful in reducing the gender gap in poverty (Kabeer 2009). Women's gradual economic empowerment is expected to be followed by a decline in fertility, as well as the emergence of more educational and public sphere opportunities for all, including girls, and an overall erosion of inequalities based on ascription (Charles 2011). Among richer countries, researchers have in fact demonstrated a positive relationship between economic growth and gender equality as measured by GEM (Forsythe et al 2000) or by standard poverty indicators (Wieping and Mass 2005).

These conflicting views on the impact of structural adjustment policies may be easier to reconcile if we examine the SAP elements separately focusing on a single dimension of gender inequality and in a relatively homogenous context. We pursue this 
route below by formulating hypotheses about the impact of foreign direct investment, financial liberalization and the rate of economic growth on the gender poverty gap in post-state socialist societies.

In the beginning of the $21^{\text {st }}$ century the rate of average economic growth in Central and Eastern Europe exceeded that in the other EU member states. Yet variations were significant among the ten post-socialist countries: the annual growth in Hungary in 2007 was registered at less than $1 \%$ but over $10 \%$ in Slovakia. The Baltic countries, especially Estonia posted similarly vigorous growth rates before 2008 .

Hypothesis 1a: In CEE gender inequality in poverty is expected to be larger in countries, which exhibit higher rates of growth (net of their level of development). As the arguments we presented above suggest such growth may be realized through keeping wages low and offering informal jobs amidst bleak work conditions. Indeed, the median wage in post-state socialist countries is significantly lower than the EU average and according to a recent ILO report (2014) a growing proportion of the employed population works in "vulnerable jobs": informally, with temporary contracts or receiving subminimum wages (for euphemistically called "internships" or "public works"). In such contexts women may be more vulnerable than men due to discrimination based on at least two factors: women's and especially mothers' perceived lower productivity because of their domestic responsibilities, as well as widely held convictions about men's priority over women at hiring when jobs are scarce (Dunn 2004, Glass and Fodor 2011, Weiner 2007).

Foreign capital investments have had a profound impact on the Central and Eastern European transformation process. By 2007, foreign direct investment (FDI) 
stocks amounted to a third to two thirds of each country's GDP (Bandelj 2007). Foreign direct investment is correlated with a higher level of class inequality in CEE, because, among other reasons, such investments are likely to inflate the wages of highly skilled workers relative to all others (Bandelj and Mahutga 2010). These highly skilled managerial workers tend to be men, so foreign direct investment is expected to increase gender inequality as well. In addition, not all FDI's are the same. Bohle and Greskovits (2012) argue that the industries, which entered CEE after 2000 fostered especially weak labor organizations and thus foreign investors have excessive amounts of power over workers, which lead to conditions well below Western European labor standards. Thus a dependence on foreign capital in CEE resulted in a decline in workers' overall bargaining power, work security and may have exacerbated exploitation. Researchers also note that foreign direct investment in the 2000s tends to favor light industries in the less developed countries of the region; textile and food production factories offer low-skilled work opportunities predominantly for women (Dunn 2004). These feminized jobs are poorly paid, increasingly insecure and home based, thus contributing to women's vulnerability rather than improving their lot relative to men's.

Indeed, liberalization and privatization in the financial sector was pervasive in many CEE countries as it is evidenced, for example, by the proportion of foreign and state ownership of banks (Andries and Capraru 2013). The state retained absolutely no ownership in the banking sector in Estonia and Lithuania, suggesting a high degree of foreign capital dependence. In Slovenia and Poland, on the other hand, over 20\% of banks are owned and controlled by the state. In terms of overall foreign investments (FDI flows), variations are similarly large within the post-communist region. Between 
2004 and 2007, foreign direct investment dollars amounted to close to $30 \%$ of the GDP of Bulgaria, $13 \%$ of the GDP of Estonia, while it constituted less than 4\% of the GDP of Hungary and Slovenia.

Hypotheses 1b: Net of the level of economic development, countries with higher levels of FDI are expected to have higher levels of gender inequality in poverty ${ }^{2}$. This is so because we expect foreign investments in the late 2000s to be creating unstable, exploitative and vulnerable work opportunities, some in sweatshop like conditions (Bohle and Greskovits 2012). Women may be preferred for these jobs but their risk of unemployment is high and their income may not pull them out of poverty. Higher quality FDI in turn creates jobs which women are poorly positioned to compete for given their extra-work responsibilities, the amount of which has not declined in the past decades (Glass and Fodor 2011).

Hypotheses 1c. Financial de-regulation (a lack of state ownership in the finance sector) is expected to be negatively associated with the gender poverty gap. While an international financial sector may provide excellent job opportunities for a limited number of highly skilled professionals, including women, it may also lead to higher volatility, loan policies which shun social responsibility, reduced tax revenues and a reduction of state control over investments. In this context less credit may be available

\footnotetext{
${ }^{2}$ Oostendorp (2009) found no relationship between the gender wage gap and FDI in less developed countries. Poverty, however, is somewhat different from merely wages and FDI influences infrastructural developments, labor laws and employment policies, etc, which may not impact the wage gap but lead to more gender inequality in poverty.
} 
for the "riskiest" loan applicants. These factors are expected to increase workers' and especially women's economic vulnerability and thus may lead to a higher poverty gap.

\section{Austerity and the gender poverty gap}

International development agencies consider austerity in government expenditure as one of the central tenet of structural adjustment and growth. While generous welfare spending is associated with lower poverty rates in western capitalist societies (Kenworthy 1999; Korpi and Palme 1998; Moller et al. 2003), the relationship between welfare state generosity and gender equality is less straightforward. Feminist comparative research on the gender poverty gap suggested that when states provide high levels of welfare payments to people in need, the gender poverty gap will be reduced (Casper 1994; Christopher et al. 2002, Brady 2009). This is so because welfare subsidies to the poor tend to benefit women and especially women with children. Not all welfare subsidies function the same way, however. Certain family-related benefits, which provide incentives for mothers to withdraw for lengthy periods from the labor market after childbirth in a context where formal childcare arrangements are scarce, may exacerbate the gender poverty gap (Gornick and Meyers 2009; Keck and Saraceno 2013; Mandel and Semoyonov 2006; Petit and Hook 2009, Misra et al 2007).

Unlike many other developing countries, post-socialist societies entered the process of global market integration with a history of extensive state redistribution, i.e., generous pension systems, family support policies as well as others types of income redistribution measures. After 1989 a rapid retrenchment began in most countries, but different social provisions were eliminated or their real value was allowed to inflate at 
different rates as a result of political processes, international pressure and economic opportunities (Myant and Drahokoupil 2011). What the IMF called "overly generous" state redistribution has been one of the key targets of structural adjustment blueprints and as such it is closely tied to what is considered "economic development" in the region. We therefore identify variations across countries in the role of the welfare state in poverty alleviation and explore its relationship to gender inequality.

Since 1990, greater expenditure on welfare has been associated with lower overall poverty rates in CEE countries as well (Bandelj and Mahutga 2010), even though compared to "older" EU members, these countries spend a significantly lower percentage of their already significantly lower GDP on welfare. In 2007, the year preceding our survey, the 27 EU countries allocated on average $26 \%$ of their GDP on social expenditure, while social spending in CEE ranged from a low of $12.2 \%$ (in Latvia) to a high of $22.8 \%$ (in Slovenia). In terms of the actual value this percentage represents, the EU average per capita spending (at PPP) stood at 6,349 Euros (with none of the core countries spending less than 8,000 Euros), while the value of social spending ranged from 1,277 Euros to (an exceptionally high) 4,793 Euros in Slovenia ${ }^{3}$.

There is sizable variation within Central and Eastern Europe in the way this spending is allocated which may have gendered consequences. Some countries directed greater funds to compensate pensioners and "cleared" the labor market with generous early retirement options and disability pensions, others allowed a devaluation of the value of old-age pensions (Bohle and Greskovits 2012). The average pension to wage ratio was

\footnotetext{
${ }^{3}$ http://epp.eurostat.ec.europa.eu/cache/ITY_PUBLIC/3-02062009-BP/EN/3-02062009BP-EN.PDF
} 
$72 \%$ in Poland and around $60 \%$ in Hungary in the mid 1990 s, but only around $30 \%$ in Estonia and Latvia (Myant and Drahokoupil 2011: 201). Since women outnumber men among the unpartnered elderly, the variation in the value of pensions will explain some of the cross-country differences in the gender poverty gap. Another, smaller, but identifiable group in poverty is that of lone mothers. Many CEE countries grant generous parental leaves and child care allowances to women on the assumption that they will spend a significant portion of their adult lives financially dependent on their families and/or on a relatively poor state - a strategy which might increase both short and long term poverty risks for all women and especially mothers. However, variation among the countries is sizeable. In 2007 , Hungary spent $3.4 \%$ of its GDP on family protection measures, while similarly targeted measures only received a little over $1 \%$ of the GDP in many other societies (for example in Latvia, Lithuania or Bulgaria). This amount is typically spent on parental leave payments, family tax breaks or cash benefits to parents with children.

Hypothesis 2a: We expect overall social spending to be negatively associated with the gender poverty gap: countries, which spend more on social welfare are expected to experience less gender inequality in poverty. Social spending has both a direct and indirect effect on women's well-being. Its direct effect is expected to be expressed through providing welfare benefits to those in need. In an indirect way, social spending is expected to reduce women's domestic work burden through the provision of services (such as health and educational services, elderly care, etc), thus free them for participation in the labor market. 
Hypotheses $2 \boldsymbol{b}$ : Countries, which spend a higher percentage of their GDP on family related benefits may in fact have a larger gender poverty gap. These subsidies in CEE countries, where they are primarily spent on lengthy parental leave provisions may increase the poverty risk of women with children as they provide disincentives for them to return to the labor market yet are not generous enough to lift them out of poverty. This is expected to be true not only for women who currently raise small children, but also for women who had taken the leave earlier and had trouble returning to work afterwards or must accept reduced pension benefits as a result. Instead of creating work opportunities and financing education for small children, conservative family policies may cements mothers' marginalization in the labor market.

Hypotheses 2c: Countries, which spend a higher percentage of their GDP on pension related benefits will have smaller gender poverty gaps. The restructuring and generosity of pension payments is expected to reduce pensioners' risk of poverty and since women outnumber men amongst the elderly, it is also expected to lead to a smaller gender poverty gap.

In the rest of the paper we test these two sets of hypotheses, related first to macroeconomic measures and second, to state austerity. We emphasize that we are really examining the same phenomenon from somewhat different, albeit related angles: the impact of what we call "economic development" on the gender poverty gap.

\section{DATA AND ANALYTICAL STRATEGY}

\section{Sample}


We included ten post-communist EU member states in this project: Bulgaria, the Czech Republic, Estonia, Hungary, Latvia, Lithuania, Poland, Romania, Slovakia and Slovenia. This was the whole population of post-socialist EU member societies in $2008^{4}$. We selected these countries instead of using information from all EU member states because we were specifically interested in the impact of structural adjustment and neo-liberal policy initiatives on gender inequality during global market integration. While austerity measures have certainly been introduced in other parts of Europe as well, structural adjustment, the emergence of capitalist markets and the novelty of participating in the global economy are unique to CEE countries. In addition, the consequences of similar policies or macro-economic phenomena take on quite different meanings here compared to more developed regions. Two examples should highlight this latter point. First, while foreign direct investments are important for the economy of a number of EU countries, transnational companies operate quite differently in core countries, such as in Belgium or Norway than in peripheral ones, such as in Bulgaria or Poland. The difference in the quality of jobs they offer has important consequences for the life chance of their workers, their social vulnerability and chances of poverty. The impact of foreign direct investment is thus not the same in core and semi-peripheral countries ${ }^{5}$. Second, consider the meaning of "austerity" at different levels of development. Cutbacks in state spending on health care, even if the same in percentage terms, means something quite different for,

\footnotetext{
${ }^{4}$ In 2013 Croatia entered the European Union.

${ }^{5}$ Because of the differences in the quality, volume and workings of FDI, Central and East European countries are classified as "dependent market economies" in recent political science literature (Noelke and Vliegenthart 2009).
} 
for example, health (and poverty) outcomes at different levels of spending as sizable variation in mortality/ morbidity between CEE countries and "older" EU members states amply demonstrate.

In addition, post-socialist countries share a number of unique features, which differentiate them from other countries and which are the consequences of their state socialist past and their geo-political location at the peripheries of the European Union ${ }^{6}$. The factors relevant for our paper include a history of women's labor force participation and of lengthy parental leaves, very early retirement thresholds especially for women, a high proportion of extended families, the dearth of part-time work options, weak to nonexistent labor unions and lax labor legislations, as well a significantly lower standard of living, much higher levels of absolute or subjective poverty, lower wages and an increased vulnerability especially in old age and among single parents ${ }^{7}$. These characteristics all profoundly shape gender inequality in poverty. To hold these as constant as possible in order to be able to focus on the impact of structural adjustment net of these other factors, we decided to limit our sample to CEE countries only. ${ }^{8}$

${ }^{6}$ Indeed, recent research on the impact of the economic crisis of 2008 also highlight the fact that macro-economic change may affect gender relations and women's social status differently in core and (semi)-peripheral countries of the EU (Bettio et al 2012).

${ }^{7}$ While some core countries may also share some of these features, the coherence in this regard among CEE countries is notable.

${ }^{8}$ Several studies have included a handful of post-socialist countries in larger samples of developed and developing nations (for example, Pettit and Hook 2009, Barcena-Martin and Moro-Egido 2013, Hook 2006, etc). Given their different focus, these studies do not 
The individual level samples come from the 2008 wave of the European Union Statistics on Income and Living Conditions (EU-SILC 2008) ${ }^{9}$. These are large representative surveys of individuals as well as households of all EU member countries. For our analysis we selected un-partnered individuals, i.e. people who did not, at the time of the survey, share their household resources with a partner (see also Wieping and Maas 2005, or Elena Bárcena-Martín and Ana I. Moro-Egido, 2013). Given that in EU-SILC poverty is measured at the level of the household with the assumption of equal sharing, the gender gap can only be measured among the unpartnered. Our sample group includes single individuals without children, both elderly and younger as well as parents raising children without a partner present in the household. Because of this criterion we reduced our sample size to 69,293 for the ten countries altogether ${ }^{10}$.

control for the historical legacies of state socialism listed above and thus ignore the context within which the independent variables gain meaning. Our explorations should contribute to and nuance these findings by isolating the impact of macro-economic and institutional predictors of gender inequality in a specific historical/ economic setting. ${ }^{9}$ The choice of 2008 is deliberate: we selected the last pre-crisis year for our analysis. Macro-economic indicators became extremely volatile during the crisis years, so their usefulness for other than describing this period is doubtful, especially since international statistics already indicate a gradual return to previous levels of gender inequality, growth, poverty, etc.

${ }^{10}$ This process introduces an obvious selection bias, thus we will be careful with generalizations to the whole population of women. 


\section{The dependent variable}

The dependent variable in our models is the risk of poverty in $2008^{11}$. We employ the definition of poverty typically used for cross-national comparisons and consider someone poor whose per capita equivalized household income is less than $60 \%$ of his/her country's national median. This is a relative measure and thus is an indication of inequalities at the bottom of the social hierarchy rather than absolute levels of deprivation. The overall poverty rate so defined was $20.5 \%$ among un-partnered individuals in the ten countries with $22.6 \%$ of women and $17.5 \%$ of men living in poverty $^{12}$. These percentages, however, vary by country. Figure 1 (and columns 1-3 of table 1) shows the distribution of our dependent variable, the rate of poverty in each country broken down by gender. The countries are arranged from low to high in terms of the gender poverty gap. On the left -hand side, women are slightly less likely to be poor than men in Hungary and Poland, but the other countries exhibit sizable gender gaps to women's disadvantage ranging from 1.2 in Slovenia to 1.8 in the Czech Republic. The difference (rather than ratio) of men's and women's poverty shows a roughly similar ranking among the countries (table 1, column 4), with the Czech Republic ranked lower and Bulgaria, Latvia and Romania at the top. These percentages are higher than the

\footnotetext{
${ }^{11}$ We will measure the gender poverty gap, i.e., women's risk of poverty relative to men's risk, our main interest, by interpreting the effect of gender on a person's "risk of poverty".

${ }^{12}$ In the whole sample, the poverty rate in the ten countries is $17.4 \%$, for women $18.1 \%$ and for men $16.7 \%$, see table 1 .
} 
overall poverty rate in the population (except in Slovenia) suggesting that the risk of poverty is higher among those living without a partner.

--- Figure 1 and Table 1 about here ---

\section{Independent variables}

Individual level

We included a range of individual characteristics, which are known to influence people's chance of poverty. The distribution of these variables can be found in table 2 .

--- Table 2 about here ---

It is immediately obvious that there are many more un-partnered women than men living in the ten post-socialist countries, primarily explained by the large gender gap in life expectancy in this region and the fact that women are more likely to live without a spouse later in life. While roughly half of the full sample are women, about $60 \%$ of unpartnered individuals are. Age is coded in years and the average age for unpartnered women (48.4) is higher than that of men (34.3) for the reasons we cite above. We included a separate term for those over 65 ("elderly") to account for the possible non-linear impact of age on the odds of poverty ${ }^{13}$. We entered education as a set of two dummy variables (secondary only, and college or more), as well as another binary variable to designate the work status of the person. This variable is coded 1 if the person self-identifies as "working for

\footnotetext{
${ }^{13}$ We also ran the models with age and a squared term for age to capture non-linearity and the results were similar.
} 
wages", and 0 otherwise. Unpartnered women are more likely to have a college degree than unpartnered men but men are more likely to be at work, given that they are typically younger and less likely to be retired. Finally we included a variable to describe family status (note that everyone is "unpartnered"): those who have children in the household under 12 and those who do not. These people are not necessarily single parents in the traditional sense of the term but may be living with others, such as for example, their own parents or their grandchildren. Non-nuclear households are especially popular in Central and Eastern Europe so we included a variable coded 1, if the person lives in a household, which includes more than two adults and 0 otherwise. Over $20 \%$ of unpartnered individuals live in non-nuclear households, more men than women do.

Based on the vast literature on individual level predictors of poverty, we expect education and work status to lower the risk, while age, especially being elderly, as well as having small children in the household to increase the risk of destitution. In separate models we also included a dummy variable, which described the size of the settlement where the person lived, but as this variable is unavailable for Slovenia we did not include it in our multi-level models where the $\mathrm{N}$ at the country level is too small to afford the exclusion of a country. The variable is significant, people in urban areas are less likely to be poor in Central and Eastern Europe, but does not influence the impact of gender which is our interest here.

\section{Societal level independent variables}

Our main interest is in the effect of societal level factors and their interaction with gender in predicting poverty rates. We modeled six macro-level independent variables, each 
corresponding to one of our hypotheses. These variables are lagged one year; they describe the year 2007, while our survey data were collected in 2008. Most of the data come from Eurostat's dataset and website. For a detailed description of the variables and their sources, see Appendix B.

-- Table 3 about here -

The level of economic development is measured as the country's per capita GDP at purchasing power parity in 2007. All post-state socialist economies cluster towards the bottom of the GDP distribution among European Union countries, although variations across them are also notable. By 2007 none of them reached the EU average but Slovenia's level of development was only 10 percentage points lower, while the Bulgarian and Romanian GDP's were merely about $40 \%$ of the EU average. Because of these differences across the countries as well as the known association between per capita GDP and both the level of absolute poverty and the generosity of welfare subsidies, we will use the level of GDP in 2007 as a control variable in all the models we specify below $^{14}$.

${ }^{14}$ We do not formulate a hypothesis about the level of GDP and gender inequality for two reasons. While the literature suggests a curvilinear relationship between gender inequality and development (less inequality at very low and very high levels of development), this finding is based on datasets, which include a much wider range of levels of development than what we have in our sample. Second, our paper focuses on the impact of structural adjustment policy initiatives, but the level (rather than the rate of 
Economic growth describes the 3-year average of the country's real GDP growth between 2005 and 2007. We experimented with a measure for longer term growth (between 1999 and 2007) but the two are highly correlated and the results did not differ from each other, so we opted to use the short term growth measure. ${ }^{15}$ We measured the level of foreign direct investment flow in each country as a percent of its GDP as the average of the three years between 2005 and $2007^{16}$. We also add a measure of financial openness: the proportion of banking sector owned by the state as opposed to foreign or domestic private investors.

To assess the generosity of the welfare state we used a measure of the country's total expenditure on social protection in 2007 as a percentage of its GDP, as well as the growth) of GDP is more closely associated with the legacies of the state socialist period than with more recent measures. Finally, previous research on the gender poverty gap found no relationship between the level of GDP and gender inequality in poverty (Wieping and Maas 2005).

${ }^{15}$ Given that this variable now describes the previous few years, it may pick up the impact of sudden changes in the economy and their consequences for increasing/ decreasing people's risk of poverty.

${ }^{16}$ An alternative measure, the volume of FDI stock is highly correlated with FDI flow (.7) and yield similar results. We believe the immediate and rapidly changing impact of FDI's are better captured by this measure for our purposes (for a careful argument about the impact of foreign investment outflows see for example, Alderson and Nielsen 2002) 
level of pension expenditure and family expenditure as a percentage of the GDP, to assess how more targeted benefits ease gender inequality.

These variables cluster to form countries with specific characteristics. The Baltic region represents one such cluster, which Bohle and Greskovics (2012) call "neo-liberal capitalism." Note that variation among the countries even within this group is significant. Nevertheless, these countries are typically characterized by high growth rates, high and rapidly increasing rates of foreign investment and financial de-regulation as well as a withdrawal of the state from the provision of social services (Estonia is the farthest developed in this regard). At the other end of the spectrum we find Hungary, Poland, Slovenia and the Czech Republic ("embedded neoliberalism”, according to Bohle and Greskovits, 2012) with high rates of social spending, accompanied by slower growth and less foreign capital penetration. Slovenia stands out as the country, which is the least "open" in the sense that foreign capital penetration is the smallest overall and specifically in her financial markets. The two countries at the bottom of the GDP distribution, Bulgaria and Romania follow rather different paths. Neither can afford to allocate much to social spending but Bulgaria in the years prior to the economic crisis received an exceptionally great deal of foreign investment especially in light industries and services, such as tourism and textiles, pushing it closer to the neo-liberal strategies of the Baltic region than to Central Europe.

These clusters, including their history and the geo-political reasons behind their political/economic choices, have been described elsewhere. We find the construction of such typologies useful, but we also note vast variations within these clusters, especially when contrasted with the outcome of gender inequality in poverty. We therefore examine 
the impact of each variable first and in the conclusion of the paper return to the usefulness of mainstream typologies for analyzing gendered consequences.

Above we argued that our macro-level variables describe different facets of "economic development" which are separated only for the purposes of analysis. This becomes even clearer when we observe the correlations among the independent variables on the macro level (the correlation table is available upon request). There is a strong association between each type of social spending and growth rates, supporting the argument that growth may happen at the cost of withdrawing state responsibility for vulnerable groups. We explore the consequences below.

\section{Analytical strategy}

Given our substantive decision to restrict our analysis to post-socialist societies, the choice of analytical method is not trivial. Our data are clustered within countries, hence we are using multi-level modeling to estimate the effect of the individual and macro-level variables simultaneously without biasing the standard errors of our estimates. However, we only have 10 cases at the second (macro) level and as we mentioned above these ten cases are the whole population of post-socialist countries, which were members of the European Union in 2008 when the data were collected. Ten is admittedly a rather small number of cases for these types of models. It is, however, not impossible to model data for such a small group as long as it is done with care. In their guide to users, MLwiN's creators warn about possible problems with small macro level N's but do not rule out its use $^{17}$. Similarly, Gelman and Hills (2007) in their widely used textbook on data analysis

\footnotetext{
${ }^{17}$ http://www.bristol.ac.uk/cmm/learning/multilevel-models/samples.html.
} 
do not require a larger number of cases at the macro level and encourage the use of multilevel modeling even if the sample size is very small, even with as few as 3 cases at the macro level. There are a number of recently published examples of articles in the field of labor economics using multi-level models with fewer than the 20 cases typically recommended (see for example, Bárcena-Martín and Moro-Egido (2013), who included 17 countries in their analysis.)

Given concerns about multi-level modeling with a dataset of this type, we also performed a slightly different kind of analysis and obtained a set of two-stage regression models to check our results (Gelman 2005). This method involves running regression models separately for each country and then fitting a linear regression line to a second model with includes the coefficients (for gender in our case) from the original (in our case, logistic) regressions and the macro-level variables of interest. We also present some of the outcome from these models in a graph format ${ }^{18}$. The results generally confirm our findings obtained from the multi-level models.

We use random coefficient logistic regression models, which allow for variation both in the intercept and the slope of gender across countries and predicts the odds of being poor. In this case our main interest will be the cross-level interaction term between gender and each of the macro level variables described above. We used the software MLwiN (Rashbach, Steele, Browne and Godlstein 2009), and estimate equations of the

\footnotetext{
${ }^{18}$ Because of length limitations we do not present all the graphs here but selected a couple to demonstrate the method and make our results more accessible. All the graphs are available upon request.
} 
following type using $2^{\text {nd }}$ order PQL procedure (the default MQL procedure yields similar results):



\section{RESULTS}

Table 4 presents the unsurprising results from a multi-level random coefficient model, which includes individual level variables only. Women, net of other factors, have a higher chance of being poor than men. The odds ratio for the coefficient "woman" is 1.17 , i.e. women's odds of poverty are, net of all other factors, 1.17 times higher than that of men $\left(\mathrm{e}^{.16}=1.17\right)$. Among unpartnered individuals age has a curvilinear relationship with poverty: it increases people's odds of poverty to a point, but the elderly enjoy a lower risk than others. Education, especially post-secondary education, as well as working for wages reduces one's risk of poverty, as does living in an extended household. Having children in the household increases household members' chance of poverty. These findings confirm previous studies on the determinants of poverty for individuals. We would like to highlight one variable. Unlike in most western European countries, extended households Central and Eastern Europe are less likely to be poor than nuclear ones. Indeed, the extensive practice of the intra-household transfer of goods, money and labor in the region may serve as an important institution- besides the state and the labor market- of poverty alleviation.

-- Table 4 about here- 
Next we examine the impact of each set of macro-level variables and their cross-level interaction with the variable "woman". We calculate these in separate equations (although also controlling for the level of GDP in most cases ${ }^{19}$ ) given the small number of $\mathrm{N}$ at the macro level. Tables 5-6 present these models. The first set of factors in table 5 address theories about the pace and character of economic development and their relationship to the gender poverty gap.

Model 1.1 and 1.2 in table 5 explore the relationship between the average rate of economic growth between 2005 and 2007 and the odds of poverty controlling for individual level compositional factors and GDP per capita. We allow the intercept and the slope for gender to vary across countries and interpret the coefficient associated with GDP growth (model 1.1) and its cross-level interaction with gender (model 1.2 and figure 2). Countries with a higher rate of recent economic growth expose people to higher risks of poverty and the gender gap is also wider in these countries. This is demonstrated by the coefficient in the shaded cell in model 1.2: net of all other factors, women are more likely than men to be poor in CEE countries which experienced fast paced growth in the years prior to 2008. The results from the two-stage model in figure 2 support this point: Hungary and Poland, the two countries with odds ratios for gender under 1 (i.e. where

\footnotetext{
${ }^{19}$ The level of GDP is related to the level of poverty in a country as well as its social investment and a number of unmeasured characteristics, which may be relevant for gender inequality. This is why we chose it as a control for our models. We explain our choice of not including it as one of the hypotheses in footnote 3 . In our earlier models we confirmed a negative correlation between the level of GDP and poverty, although none among GDP and the gender poverty gap.
} 
gender is not a risk factor for poverty, net of other variables) exhibit slow growth rates but the much more unequal Baltic countries grew faster in the years prior to the economic crisis of 2008.

-- Table 5 and figure 2 about here ---

The relative size of foreign investment and the proportion of state ownership over banks in a country describe the dependence of an economy on foreign capital, which, in the context of relative underdevelopment may indicate potential social problems and vulnerabilities, or in contrast, greater opportunities. In the post-socialist region, net of the level of economic development, countries where on-going foreign investment constitutes a bigger part of the GDP and where banks are exclusively in the hands of international capitalists, are burdened with higher levels of poverty (in line with the findings of larger social inequalities, see Bandelj and Mahutga 2010). ${ }^{20}$ In addition, women's relative risk of poverty is higher in countries which had been more deeply exposed to foreign capital. The positive cross-level interaction term in the shaded cell of model 1.4 indicates that the higher the rate of FDI flow in an economy, the larger the gender poverty gap, and the negative cross-level interaction term in model 1.6 shows that the lower the proportion of state owned banks, the higher is women's risk of poverty relative to that of men, even net of the overall level of economic development in the country.

\footnotetext{
${ }^{20}$ The relationship held steady even if we controlled for various measures of class inequality, such as the Gini coefficient or the ratio of income quintiles.
} 
Welfare spending is associated both with the level of social inequalities and with economic development. Hence in the second set of models, we control for the level of GDP and explore the impact of a variety of social benefits on the gender poverty gap. The generosity of social benefits, pensions, and (as opposed to our expectations) even family benefits are negatively correlated with the overall risk of poverty (table 6 , models 2.1, 2.3 and 2.5). In addition, countries, which spend a higher percentage of their GDP on social protection, and specifically a higher percentage of their GDP on pension and family protection measures, display smaller gender inequality at the bottom of the social hierarchy (models 2.2, 2.4, 2.6, figure 3). The cross-level interaction term between gender and pension spending is especially strong. Observe the output from the two-stage models in figure 3, which demonstrates the same rather strong correlation between the percent of GDP spent on pensions and women's relative risk of poverty. Note that women's poverty rate is especially high in Bulgaria or Latvia, where social insurance payments in old age are meager. Hungary and Poland can be found at the opposite end of the spectrum: here the level of pension payments kept up better with the inflation rate and were less devalued during the two decades following 1990. The two-step models allow the identification of exceptions: the Czech Republic is an interesting case as state spending on pensions is quite high, yet the gender gap in poverty is also one of the highest in the region, suggesting that the gap is less closely related to social insurance than elsewhere.

In general, the level of old age pension payments is particularly important in the postsocialist region, where retirement age is lower than in most developed countries, the life expectancy gap between men and women is large, and where the employment rate of 
older people, women especially, is also significantly lower than the international average (Eurostat, 2008). The combination of these factors, as well as the unavailability of private pension savings in this cohort because of the state socialist period, increases the importance of state provided pension payments. The finding related to family benefits is contrary to our hypothesis. We expected family protection in the CEE region to serve to marginalize women and increase their poverty chances because of the difficulty to return to the labor market after a leave, which together with the low level of social insurance received during the leave period may result in reducing women's expected income in old(er) age. Our models (2.5 and 2.6 in table 6) suggest the opposite. At least by 2007, family benefits serve as protection against poverty, especially for women (see also, Förster and Tóth 2000). This, however, may change, as the cohort of women who had spent long years on parental leave after 1989, rather than during the state socialist era, start entering retirement in about a decade.

--Table 6 and figure 3 about here -

\section{DISCUSSION AND CONCLUSION}

Scholars studying the impact of "economic development" have demonstrated both positive and negative associations between foreign investment, trade and financial liberalization, fast-paced growth, state austerity and gender inequality. To contribute to this debate we set out to examine the consequences of these elements of the structural adjustment package in a context where women are expected to be less vulnerable than in other developing regions. Our analysis suggests that within Central and Eastern Europe 
the gender poverty gap is larger in countries, which are currently undergoing fast-paced, foreign capital -led economic growth, and where, perhaps most important and closely related to this, welfare spending is lower and especially spending on pensions and family policies is meager. These elements of the structural adjustment package are closely connected both in actual policy making practice and in political discourse.

There are a number of reasons why fast paced, foreign capital lead economic growth would be associated with gender inequality. Countries in this category focus most of their resources on achieving growth which does not translate (or has not yet translated) into well-being for the most vulnerable: women struggling to maintain independent households, especially elderly women and women who care for dependent children. Having paid employment helps people avoid poverty, but a sizeable segment of the population earns the minimum or close to the minimum wage, which in Central and Eastern Europe represents a smaller portion (only about 35\%) of the average wage than in more developed countries ${ }^{21}$ and is therefore not necessarily enough to lift families out of poverty. For example, in 2008 a Hungarian working mother making the minimum wage and raising a child alone would have fallen some 200 Euros short of what the Hungarian Statistical Office set as the subsistence minimum and she would have to make about $180 \%$ of the minimum wage to be able to surpass the poverty threshold on her wages alone. $^{22}$ Given the ubiquity of low wage, unstable employment in Central and Eastern Europe, especially for people with lower levels of education and those with care

\footnotetext{
${ }^{21}$ Eurostat, Statstics in Focus, 2008. http://www.stockwatch.com.cy/media/announce_pdf/2008$11 /$ minimum $\% 20$ wages.pdf

${ }^{22}$ Data from the National Statistical Office of Hungary and using a 2008 average Euros to HUF exchange rate of $250 \mathrm{HUF} / 1$ Euro. http://www.ksh.hu/docs/hun/xftp/idoszaki/letmin/letmin08.pdf and http://www.ksh.hu/docs/hun/xstadat/xstadat_eves/i_qli041.html.
} 
responsibilities, having a job is not a guarantee for avoiding destitution either in the short and especially not in the longer run.

In addition, in many post-socialist countries a third to half of the adult population is jobless, have no chance of finding stable work or holding on to a paid position lacking adequate childcare and social support. Indeed, the unavailability of affordable childcare is the main reasons why in many CEE countries mothers drop out of the labor market for extended periods of time, which increases their own and their families' risk of poverty. In this context, the real question is how many members of this group can escape destitution and what institutions they can rely on for support. The jobless, among whom women outnumber men, would only be helped by a type of economic development, which retains the social safety net and creates decent and stable employment accessible for people with care responsibilities. Austerity measures meant cut backs on exactly these services, such as education and child care, or social services for the elderly, which increased the pool of the most vulnerable. This research has confirmed that the state has a vital role in mediating the impact of structural adjustment policies on the poor, and especially poor women. Indeed, many other ways in which the state matters have not been considered here (for example, public sector employment, setting conditions for foreign direct investment, spending on infrastructural developments, etc) and remains to be studied in the future.

It is important to note that poverty in post-socialist countries typically entails more dire living conditions than in more developed regions, thus the day-to-day reality of gender inequality are harsher here. In Europe's fifteen most developed countries about $20 \%$ of poor people live in what is defined as overcrowded housing conditions, while in 
Central and Eastern Europe $50-68 \%$ of poor people do. ${ }^{23}$ Severe material deprivation is also more likely to be noted in the CEE region than in other parts of Europe. In Bulgaria, for example, over $40 \%$ of people lacked resources considered basic for acceptable living conditions, while in Slovakia about 27\%, in the Czech Republic $16 \% .{ }^{24}$ Compare this to the average in core EU countries at 5.8\%. Deprivation has serious consequences for people's physical and mental health, as is evidenced by high rates of alcoholism and a reduced life expectancy not only among men but also among women in post-socialist countries $^{25}$.

Mainstream political-historical research has proposed typologies to describe the developmental paths of post-communist societies. Their usefulness for studying gender inequality at the bottom of the social hierarchy is doubtless but their limitations are also clear. For example, our research confirms the conceptualization of a Baltic model: even though more women are engaged in paid work, poor women fare rather badly relative to men in Estonia, Lithuania and Latvia, where they are radically exposed to and seem to suffer the consequences of structural adjustment policies. Family benefits and pension payments are notoriously low in these countries and given their excessive wage gaps, women are disadvantaged relative to men both at work and in old age. There is no observable gender poverty gap in Hungary and Poland, both countries have so far managed to at least partially resist the insistence of international lenders for austerity

\footnotetext{
${ }^{23}$ Eurostat, http://epp.eurostat.ec.europa.eu/portal/page/portal/income_social_inclusion_living_conditions/data/main ta bles, accessed September 1, 2014. Data for 2008.

${ }^{24}$ Eurostat, http://epp.eurostat.ec.europa.eu/tgm/table.do?tab=table\&init=1\&language=en\&pcode=tessi080\&plugin=1, accessed Sept 1, 2014. Data for 2008.

${ }^{25}$ World Health Organization. Status Report on Alcohol and Health in 35 European countries. 0017/190430/Status-Report-on-Alcohol-and-Health-in-35-EuropeanCountries.pdf
} 
while simultaneously courting foreign investors. Even though a much smaller percentage of women work for wages in these two countries than in the Baltic region, pension reforms in the 1990s achieved a higher level of social security for older people, and thus a lower poverty rate for elderly women.

Nevertheless, it is the exceptions, which may be most interesting. We observed the largest gender poverty gaps in the Czech Republic and Bulgaria, in the context of overall low poverty rates in the former and very high ones in the latter ${ }^{26}$. No researcher has ever listed these two countries in the same group of any typology. Bulgaria is one of the poorest, while the Czech Republic one of the richest post-state socialist country, typically grouped together with Hungary and Poland. The rate of foreign investment is exceptionally high in Bulgaria, while about average in the Czech Republic. In addition, there are important differences in the types of investments typically made in the two countries and their level of industrialization, labor costs and production cultures, etc. Social spending is relatively high in the Czech Republic, while it is quite low in Bulgaria. Women may take lengthy, well paid leave to care for a new child in the Czech Republic, while the decently enumerated portion of parental leave is shorter in Bulgaria. These and further differences suggest that there are different paths towards gender inequality in poverty in the post-communist context. Specifically, while in Bulgaria, low levels of social protection and the vulnerability and low quality of work in multinational

\footnotetext{
${ }^{26} \mathrm{We}$ have found these two countries to have the largest gender poverty gap among CEE countries in 2010 and 2012 as well, and the Czech Republic has by far the largest gap in 2006 (no data were collected in Bulgaria in that year yet). These are the authors' calculations using the 2006, 2010 and 2012 waves of EU -SILC.
} 
companies, as well as overall large social inequalities contribute to the gender poverty gap, in the Czech Republic the causes are more likely found in the long-term withdrawal of mothers from the labor market, their difficulty to return and consequent impoverishment in the short run as well as by the time they reach pension age. It is these paths that further research may seek to identify and explain.

Gender inequality is a multi-dimensional phenomenon. While Estonia, for example, has a sizeable gender poverty gap as well as the largest wage gap and extremely high levels of job segregation in the European Union, gender differences in access to paid work are smaller there than elsewhere. Conversely, while women are not disadvantaged at the bottom of the social hierarchy relative to men in Hungary, women's and especially mothers' employment opportunities are especially unequal. The gender gap in poverty, while important, is thus only one of the dimensions along which gender regimes should be characterized. 


\section{Appendix A: Tables and figures}

Figure 1. Poverty rates for un-partnered women and men in ten post-communist societies in CEE.

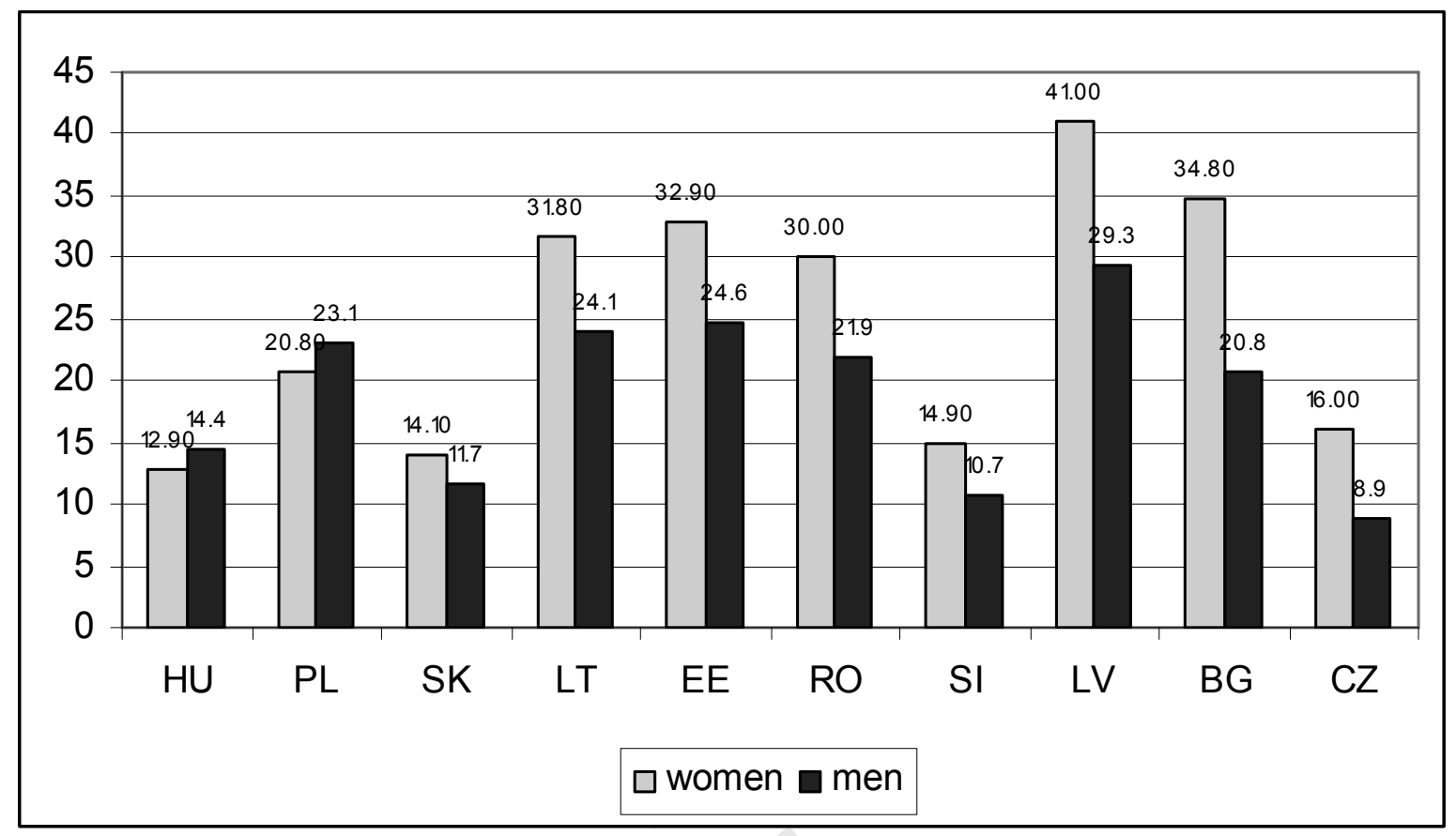

Source: EU_SILC, 2008 
Figure 2. Results from a two-stage regression model: economic growth and women's disadvantage in poverty. EU SILC 2008.

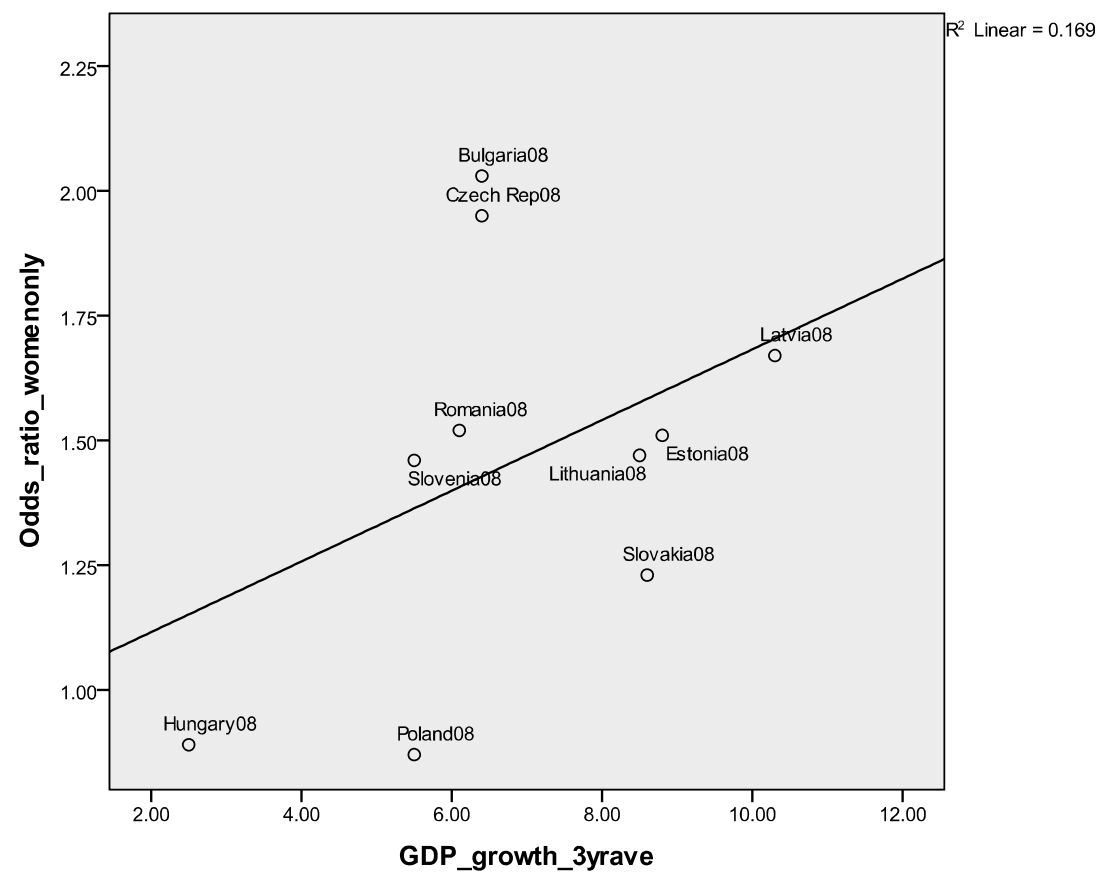


Figure 3. Results from a two-stage regression model: spending on pensions and women's disadvantage in poverty.

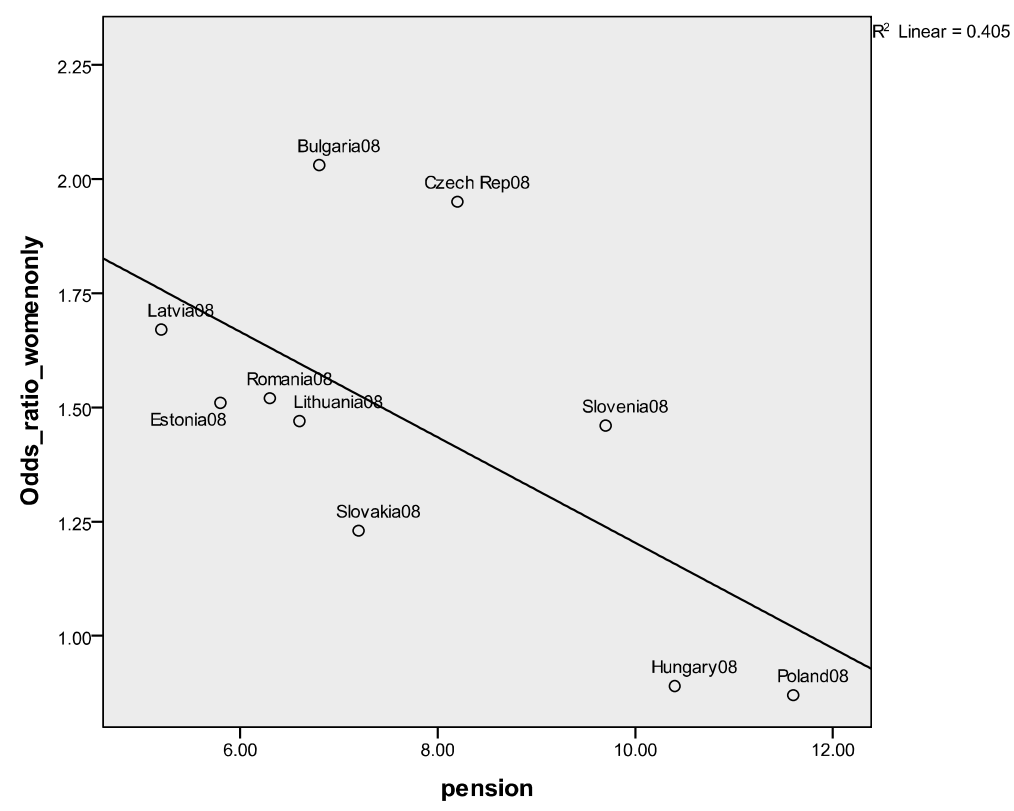


Table 1. Distribution of the dependent variable among individuals over 17 years or older.

\begin{tabular}{|l|c|c|c|c|c|c|c|c|}
\hline & $\begin{array}{c}\text { Per cent } \\
\text { poor among } \\
\text { un- } \\
\text { partnered } \\
\text { women }\end{array}$ & $\begin{array}{c}\text { Per cent } \\
\text { poor among } \\
\text { un- } \\
\text { partnered } \\
\text { men }\end{array}$ & $\begin{array}{c}\text { Per cent } \\
\text { poor among } \\
\text { all un- } \\
\text { partnered }\end{array}$ & $\begin{array}{c}\text { Ratio } \\
\text { (women's } \\
\text { rate/men' } \\
\text { s rate) }\end{array}$ & $\begin{array}{c}\text { Poverty } \\
\text { difference } \\
\text { (women's } \\
\text { rate } \\
\text { minus } \\
\text { men's } \\
\text { rate) }\end{array}$ & $\begin{array}{c}\text { Overall } \\
\text { poverty } \\
\text { rate in } \\
\text { full } \\
\text { populati } \\
\text { on over } \\
\text { 18 }\end{array}$ & $\begin{array}{c}\text { N } \\
\text { (full } \\
\text { sample) }\end{array}$ & $\begin{array}{c}\text { N (un- } \\
\text { partnered) }\end{array}$ \\
\hline Hungary & 12.9 & 14.4 & 13.5 & 0.90 & -1.5 & 11.0 & 18,378 & 8,138 \\
\hline Poland & 20.8 & 23.1 & 21.7 & 0.90 & -2.3 & 17.1 & 33,110 & 12,134 \\
\hline Slovenia & 14.1 & 11.7 & 12.9 & 1.21 & 2.4 & 11.2 & 24,615 & 10,125 \\
\hline Latvia & 41.0 & 29.3 & 36.9 & 1.40 & 11.7 & 34.4 & 10,684 & 5,321 \\
\hline Estonia & 32.9 & 24.6 & 29.5 & 1.34 & 8.3 & 22.1 & 10,582 & 4,641 \\
\hline Romania & 30.0 & 21.9 & 26.5 & 1.37 & 8.1 & 23.3 & 16,242 & 5,869 \\
\hline Slovakia & 14.9 & 10.7 & 13.1 & 1.39 & 4.2 & 10.9 & 13,807 & 6,238 \\
\hline Lithuani & 31.8 & 24.1 & 28.8 & 1.32 & 7.7 & 21.1 & 10,284 & 4,059 \\
\hline a & & & & & & & \\
\hline Bulgaria & 34.8 & 20.8 & 28.9 & 1.67 & 14 & 26.3 & 10,230 & 3,784 \\
\hline Czech R & 16.0 & 8.9 & 13.0 & 1.80 & 7.1 & 8.6 & 22,431 & 8,912 \\
\hline
\end{tabular}

Source: EU-SILC, 2008. 
Table 2. Distribution of the individual level variables in the models by gender

Unpartnered individuals, full sample and lone mothers over 17 in ten post-state socialist EU member states.

\begin{tabular}{|l|c|c|c|c|c|c|}
\hline & $\begin{array}{c}\text { Unpartnered } \\
\text { women }\end{array}$ & $\begin{array}{c}\text { Unpartnered } \\
\text { men }\end{array}$ & $\begin{array}{c}\text { Unpartnered } \\
\text { all }\end{array}$ & $\begin{array}{c}\text { Full sample } \\
\text { women }\end{array}$ & $\begin{array}{c}\text { Full sample } \\
\text { men }\end{array}$ & $\begin{array}{c}\text { Full sample } \\
\text { all }\end{array}$ \\
\hline Age (mean) & 48.4 & 34.3 & 42.4 & 49.1 & 45.8 & 47.6 \\
\hline Elderly & 33.8 & 10.2 & 23.9 & 24.5 & 18 & 21.6 \\
\hline Secondary education & 73.9 & 84.5 & 78.3 & 74.4 & 79.9 & 77.0 \\
\hline College or more & 13.2 & 9.3 & 11.5 & 15.6 & 13.4 & 14.6 \\
\hline $\begin{array}{l}\text { Extended family } \\
\text { household }\end{array}$ & 19.0 & 22.4 & 20.4 & 19.2 & 20.4 & 19.7 \\
\hline Working for wages & 30.1 & 46.1 & 36.8 & 42.1 & 55.4 & 48.3 \\
\hline $\begin{array}{l}\text { Children under 12 in } \\
\text { household }\end{array}$ & 44.3 & 45.7 & 44.9 & 48.0 & 48.9 & 48.4 \\
\hline Poor & 22.6 & 17.5 & 20.5 & 17.0 & 14.3 & 15.7 \\
\hline No partner & - & - & - & 44.1 & 36.4 & 40.5 \\
\hline N & 40,201 & 29,049 & 69,292 & 81,206 & 92,294 & 173,415 \\
\hline
\end{tabular}

Source: EU-SILC, 2008. 
Table 3. Distribution of country level variables in the models

\begin{tabular}{|l|c|c|c|c|c|c|c|}
\hline & $\begin{array}{c}\text { GDP as \% } \\
\text { of EU-27 }\end{array}$ & $\begin{array}{c}\text { GDP } \\
\text { growth } \\
\text { (3 year } \\
\text { ave) }\end{array}$ & $\begin{array}{c}\text { FDI flow } \\
\text { (3 year } \\
\text { ave) }\end{array}$ & $\begin{array}{c}\text { \% state } \\
\text { owned } \\
\text { banks }\end{array}$ & $\begin{array}{c}\text { Pension } \\
\text { spending }\end{array}$ & $\begin{array}{c}\text { Social } \\
\text { protection }\end{array}$ & $\begin{array}{c}\text { Family } \\
\text { protection }\end{array}$ \\
\hline Bulgaria & 43 & 6.4 & 29.4 & 1.98 & 6.8 & 15.1 & 1.26 \\
\hline Czech R & 80 & 6.1 & 6.0 & 2.56 & 8.2 & 18.6 & 2.42 \\
\hline Estonia & 68 & 6.9 & 12.6 & 0 & 5.8 & 12.5 & 1.73 \\
\hline Hungary & 64 & 1.0 & 8.1 & 5.6 & 10.4 & 22.3 & 3.40 \\
\hline Lithuania & 62 & 9.8 & 5.2 & 0 & 6.6 & 14.3 & 1.19 \\
\hline Latvia & 57 & 10.0 & 2.9 & 7.3 & 5.2 & 11.0 & 1.17 \\
\hline Poland & 56 & 6.8 & 5.5 & 20.4 & 11.6 & 18.1 & 1.54 \\
\hline Romania & 42 & 6.3 & 5.8 & 5.8 & 6.3 & 12.8 & 1.66 \\
\hline Slovenia & 91 & 6.9 & 3.8 & 26.4 & 9.7 & 21.4 & 1.80 \\
\hline Slovakia & 72 & 10.6 & 4.8 & 1.1 & 7.2 & 16.0 & 2.19 \\
\hline
\end{tabular}

Source: see Appendix B. 
Table 4. Logistic regression coefficients (and standard errors) predicting the odds of being poor in a random coefficient model. Individual level variables included only.

\begin{tabular}{|l|c|}
\hline & $\begin{array}{c}\text { Un-partnered } \\
\text { individuals }\end{array}$ \\
\hline Woman & $.16^{*}$ \\
& $(.09)$ \\
\hline Age & $.01^{*}$ \\
& $(.00)$ \\
\hline Elderly & $-.65^{*}$ \\
& $(.04)$ \\
\hline Secondary school & $-.47^{*}$ \\
& $(.03)$ \\
\hline College graduate & $-1.5^{*}$ \\
& $(.05)$ \\
\hline Working for wages & $-.96^{*}$ \\
& $(.03)$ \\
\hline Children under 12 in & $.06^{*}$ \\
household & $(.03)$ \\
\hline Extended household & $-.46^{*}$ \\
\hline Constant & $(.03)$ \\
\hline N & $-.99^{*}$ \\
\hline
\end{tabular}

Source: EU-SILC, 2008.

Sample: Unpartnered individuals 17 and over, 10 post-state socialist EU members states.

* represents coefficients statistically significant at $\mathrm{p}<.05$ (two tailed tests). 
Table 5. Logistic regression coefficients from random coefficient models predicting odds of being poor.

Hypothesis set 1: Level, pace and pattern of economic development

\begin{tabular}{|c|c|c|c|c|c|c|}
\hline & Model 1.1 & Model 1.2 & Model 1.3 & Model 1.4 & Model 1.5 & Model 1.6 \\
\hline $\begin{array}{l}\text { Individual level } \\
\text { predictors and } \\
\text { GDP }\end{array}$ & included & included & included & included & included & included \\
\hline Woman & $\begin{array}{l}.14 \\
(.10)\end{array}$ & $\begin{array}{c}-.51(*) \\
(.26)\end{array}$ & $\begin{array}{l}.17(*) \\
(.09)\end{array}$ & $\begin{array}{l}-.10 \\
(.16)\end{array}$ & $\begin{array}{l}.17 * \\
(.09)\end{array}$ & $\begin{array}{l}.34^{*} \\
(.10)\end{array}$ \\
\hline $\begin{array}{l}\text { GDP growth } \\
\text { (3 year ave) }\end{array}$ & $\begin{array}{l}.13^{*} \\
(.03)\end{array}$ & $\begin{array}{l}.10^{*} \\
(.03)\end{array}$ & - & - & - & - \\
\hline $\begin{array}{l}\text { GDP growth } \\
\text { *woman }^{\text {wom }}\end{array}$ & - & $\begin{array}{l}.09 * \\
(.03)\end{array}$ & - & - & - & - \\
\hline $\begin{array}{l}\text { FDI flow } \\
\text { (3 year ave) }\end{array}$ & - & - & $\begin{array}{l}-.02 \\
(.02)\end{array}$ & $\begin{array}{l}.00 \\
(.03)\end{array}$ & - & - \\
\hline $\begin{array}{l}\text { FDI flow* } \\
\text { woman }\end{array}$ & - & - & - & $\begin{array}{l}.04^{*} \\
(.02)\end{array}$ & - & - \\
\hline$\%$ state banks & - &  & - & - & $\begin{array}{c}.02 \\
(.02)\end{array}$ & $\begin{array}{l}-.00 \\
(.02)\end{array}$ \\
\hline $\begin{array}{l}\% \text { state banks* } \\
\text { woman }\end{array}$ & - & 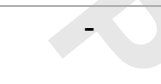 & - & - & - & $\begin{array}{l}-.03 * \\
(.01)\end{array}$ \\
\hline Constant & $\begin{array}{l}-.06 \\
(.46)\end{array}$ & $\begin{array}{l}-.49 \\
(.40)\end{array}$ & $\begin{array}{l}.65 \\
(.64)\end{array}$ & $\begin{array}{l}.49 \\
(.64)\end{array}$ & $\begin{array}{l}.29 \\
(.45)\end{array}$ & $\begin{array}{l}-.09 \\
(.19)\end{array}$ \\
\hline $\mathrm{N}$ & 69,293 & 69,293 & 69,293 & 69,293 & 69,293 & 69,293 \\
\hline
\end{tabular}

Note: GDP per capita is used as a control variable only.

Source: EU-SILC, 2008.

Sample: Unpartnered individuals 17 and over, 10 post-state socialist EU members states.

* indicates coefficients statistically significant at $\mathrm{p}<.05$ (two tailed tests)

(*) indicates coefficients statistically significant at $\mathrm{p}<.10$ 
Table 6. Logistic regression coefficients from random coefficient models predicting odds of being poor.

Hypothesis set 2: Welfare state generosity and types

\begin{tabular}{|c|c|c|c|c|c|c|}
\hline & Model 2.1 & Model 2.2 & $\begin{array}{l}\text { Model } \\
2.3\end{array}$ & $\begin{array}{l}\text { Model } \\
2.4\end{array}$ & Model 2.5 & Model 2.6 \\
\hline $\begin{array}{l}\text { Individual level } \\
\text { predictors and } \\
\text { GDP }\end{array}$ & included & included & included & included & included & included \\
\hline Woman & $\begin{array}{l}.14 \\
(.10)\end{array}$ & $\begin{array}{l}.89^{*} \\
(.39)\end{array}$ & $\begin{array}{l}.15 \\
(.10)\end{array}$ & $\begin{array}{l}1.04 \\
(.25)\end{array}$ & $\begin{array}{l}.15 \\
(.09)\end{array}$ & $\begin{array}{l}.64 * \\
(.24)\end{array}$ \\
\hline Social protection & $\begin{array}{l}-.09 * \\
(.02)\end{array}$ & $\begin{array}{l}-.08 * \\
(.02)\end{array}$ & - & - & - & - \\
\hline $\begin{array}{l}\text { Social } \\
\text { protection*women }\end{array}$ & - & $\begin{array}{l}-.05^{*} \\
(.02)\end{array}$ & - & - & - & - \\
\hline Pension & - & - & $\begin{array}{l}-.09 * \\
(-.05)\end{array}$ & $\begin{array}{l}-.07 \\
(.05)\end{array}$ & - & - \\
\hline Pension*woman & - & $\nu$ & - & $\begin{array}{l}-.12 * \\
(.03)\end{array}$ & - & - \\
\hline Family protection & - & - & - & - & $\begin{array}{l}-.34 * \\
(.14)\end{array}$ & $\begin{array}{l}-.34 * \\
(.14)\end{array}$ \\
\hline $\begin{array}{l}\text { Family } \\
\text { protection*women }\end{array}$ & - & - & - & - & - & $\begin{array}{l}-.26^{*} \\
(.13)\end{array}$ \\
\hline Constant & $\begin{array}{l}1.02 * \\
(.37)\end{array}$ & $\begin{array}{l}.75^{*} \\
(.39)\end{array}$ & $\begin{array}{l}.81 \\
(.49)\end{array}$ & $\begin{array}{l}.61 \\
(.49)\end{array}$ & $\begin{array}{l}.59 \\
(.39)\end{array}$ & $\begin{array}{l}.57 \\
(.39)\end{array}$ \\
\hline $\mathrm{N}$ & 69,293 & 69,293 & 69,293 & 69,293 & 69,293 & 69,293 \\
\hline
\end{tabular}

Source: EU-SILC, 2008.

Sample: Unpartnered individuals 17 and over, 10 post-state socialist EU members states.

* coefficients are statistically significant at $\mathrm{p}<.05$ (two tailed tests) 


\section{Appendix B. Sources and details of macro-level data}

Note: all websites last accessed June 21, 2011.

All data are for 2007 unless otherwise indicated.

\section{GDP}

Gross Domestic Product, per capita, at PPP in 2007, as a \% of EU average.

Source: Eurostat:

http://epp.eurostat.ec.europa.eu/tgm/table.do?tab=table\&init=1\&language=en\&pcode=tsi eb010\&plugin $=1$

\section{GDPgrowth- 3 year average}

Real GDP growth rate for 2005-2007, simple average.

Source: Eurostat:

http://epp.eurostat.ec.europa.eu/tgm/table.do?tab=table\&init=1\&language=en\&pcode=tsi $\underline{\text { eb020\&plugin }=1}$

\section{FDI flow}

FDI direct investment flow into the reporting country as \% of GDP, 2005-2007, simple average.

Source: Eurostat, http://epp.eurostat.ec.europa.eu/tgm/table.do?tab=table\&init=1\&language=en \&pcode=tec $\underline{00046 \& \text { plugin }=1}$

\section{Social Protection}

Total expenditure on social protection as $\%$ of GDP.

Source: Eurostat

http://epp.eurostat.ec.europa.eu/tgm/table.do?tab=table\&init=1\&language=en \&pcode=tps $\underline{00098 \& \text { plugin }=0}$

\section{Pension}

Expenditure on pensions as \% of GDP

Source: Eurostat

http://epp.eurostat.ec.europa.eu/tgm/table.do?tab=table\&init=1\&language=en\&pcode=tps $\underline{00103 \& p l u g i n}=1$,

\section{Family protection}

Public spending on family benefits in cash, services and tax measures, in per cent of GDP, 2007

Source: OECD Family database, http://www.oecd.org/document/4/0,3746,en_2649_34819 37836996_1_1_1_1,00.html

\section{\% State owned banks}

Asset share of state owned banks, 2004-7 
Source: Andries Alin Marius, and Capraru Bogdan. 2013. "Impact of Financial Liberalization on Banking Sectors Performance from Central and Eastern European Countries." PLoS ONE 8(3): e59686. doi: 10.1371/journal.pone.0059686 


\section{REFERENCES}

Alderson, Arthur S and Francois Nielsen. 2002. "Globalization and the Great U-Turn: Income Inequality Trends in 16 OECD Countries.” American Journal of Sociology, 107, 5:1244-99.

Andries, Alin Marius, and Capraru Bogdan. 2013. "Impact of Financial Liberalization on Banking Sectors Performance from Central and Eastern European Countries." PLoS ONE 8(3): e59686. doi: 10.1371/journal.pone.0059686

Bandelj, Nina. 2007. From Communists to Foreign Capitalists: The Social Foundation of Foreign Direct Investment in Postsocialist Europe. Princeton, NJ: Princeton University Press.

Bandelj, Nina, and Matthew C Mahutga. 2010. "How Socio-Economic Change Shapes Income Inequality in Post-Socialist Europe." Social Forces 88(5):2133-62.

Bárcena-Martín, Elena, and Ana I. Moro-Egido. 2013. "Gender and Poverty Risk in Europe." Feminist Economics 19(2):69-99.

Braunstein, Elissa. 2012. "Neoliberal Development Macroeconomics: A Consideration of its Gendered Employment Effects." UNRISD Research papers.

Beneria, Lourdes. 1999. Structural adjustment policies" n Janice Peterson and Margaret Lewis, eds., The Elgar Companion to Feminist Economics, Cheltenham, UK, and Northampton, USA, Edward Elgar 1999.

Beneria, Lourdes. 2003. Gender. Development and Globalizaton: Economics as if All People Mattered. New York, NY: Routledge.

Berik, Gunseli, Yana van der Meulen Rodgers, and Stephanie Seguino. 2009. "Feminist Economics of Inequality, Development and Growth." Feminist Economics 15(3):1-33.

Bettio, Francesca, Marcella Corsi, Carlo D'Ippolito, Antigone Lyberaki, Manuela Samek Lodovici, and Alina Verashchagina. 2012. "The Impact of the Economic Crisis on the Situation of Women and Men and on Gender Equality Policies." The European Network of Experts on Gender Equality: European Commission, Directorate General for Justice.

Bohle, Dorothee, and Bela Greskovits. 2012. Capitalist Diversity on Europe's Periphery. Ithaca, NY: Cornell University Press.

Boserup, Ester. 1970. Women's Role in Economic Development. London: Earthscan.

Brady, David. 2009. Rich Democracies, Poor People: How Politics Explain Poverty. Oxford, UK: Oxford University Press. 
Casper, Lynne, McLanahan, Sara, Garfinkel Irwin. 1994. "The Gender Poverty-Gap: What We Can Learn From Other Countries." American Sociological Review (59):594605.

Charles, Maria. 2011. "A World of Difference: International Trends in Women's Economic Status." Annual Review of Sociology 37(17).

Christopher, Karen, Paula England, Timothy M. Smeeding, and Katherin Ross Phillips. 2002. "The Gender Gap in Poverty in Modern Nations: Single Motherhood, the Market, and the State." Sociological Perspectives 45(3):219-42.

Dorius, Shawn F, and Glenn Firebaugh. 2010. "Trends in Global Gender Inequality." Social Forces 8(5):1941-68.

Drahokoupil, Jan. 2009. Globalization and the State in Central and Eastern Europe. London and New York: Routledge.

Dunn, Elizabeth. 2004. Privatizing Poland: Baby Food, Big Business and the Remaking of Labor. Ithaca, NY: Cornell University Press.

Einhorn, Barbara. 1993. Cindarella Goes to Market: Citizenship, Gender and Women's Movements in East Central Europe. London, New York: Verso.

Elson, Diane. 2009. "Gender Equality and Economic Growth in the World Bank World Development Report 2006." Feminist Economics 15(3):35-59.

Enloe, Cynthia. 2000. Bananas, Beaches and Bases: Making Feminist Sense of International Politics. Updated Edition with a New Preface. Berkeley CA: UC Press.

Fodor, Eva. 1997. "Gender in transition: Unemployment in Hungary, Poland, and Slovakia." East European Politics and Societies 11(3):470-500.

Forsythe, Nancy, Roberto Patricio Korzeniewicz, Valeria Durant. 2000. "Gender Inequalities and Economic Growth: A Longitudinal Evaluation." Economic Development and Cultural Change 48(3):573-81.

Forster, Michael and Istvan Gyorgy Toth. 2000. "Trends in Child Poverty and Social Transfers in the Czech Republic, Hungary and Poland: Experiences from the Years after Transition" Luxembourg Income Study, Working Paper 226.

http://www.tarki.hu/adatbank-h/kutjel/pdf/a417.pdf

Gelman, Andrew C. 2005. "Two-Stage Regression and Multilevel Modeling: A Commentary." Political Analysis (13):459-61.

Gelman, Andrew, and Jennifer Hills. 2007. Data Ananlysis Using Regression and Multilevel/hierarchical Models. Cambridge MA: Cambridge University Press. 
Ghodsee, Kristen. 2005. The Red Riviera: Gender, Tourism, and POstsocialism on the Black Sea. Durham, NC: Duke University Press.

Glass, Christy. 2008. "Gender and work during the Transition: Job Loss in Bulgaria, Hungary, Poland and Russia." East European Politics and Societies 22(4):757-83.

Glass, Christy, and Eva Fodor. 2011. "Public Maternalism Goes to Market: Recruitment, Hiring and Promotion in Postsocialist Hungary." Gender\&Society 25(1).

Gornick, Janet C, and Marcia K Meyers. 2009. "Institutions that support gender egalitarianism in parenthood and employment." in Earning and Caring: Creating the Conditions for Gender-Egalitarian Families, edited by Marcia K. Meyers Janet C. Gornick, Eric Olin Wright. New York: Verso.

Hamm, Patrick, Lawrence P. King, and David Stuckler. 2012. "Mass Privatization, State Capacity, and Economic Growth in Post-Communist Countries." American Sociological Review 77(2):295-324.

Hook, Jennifer L. 2006. "Care in context: men's unpaid work in 20 countries 1965-2003." American Sociological Review (71):639-60.

Inglehart, Ronald F, and Pippa Norris. 2003. Rising Tide: Gender Equality and Cultural Change Around the World. New York, NY: Cambridge University Press.

International Labour Organization. 2014. Transitioning from an informal to a formal economy. International Labour Conference, Report V. Genera: ILO.

Isaksen Lise Widding, Sambasivan Uma Devi and Arlie Russell Hochschild. 2010. Global Care Crisis: A problem of Capital, Care Chain or Commons. American Behavioral Scientist, 52, : 405-425.

Fernandez-Kelley, Patricia. 1983. For We Are Sold, I and my People: Women and Industry in Mexico's Frontier. Albany: State University of New York Press.

Kabeer, Naila. 2009. World Survey on the Role of Women in Development. UN Divisions for the Advancement of Women.

http://www.un.org/womenwatch/daw/public/WorldSurvey2009.pdf

Keck, Wolfgang, and Chiara Saraceno. 2013. "The Impact of Different Social-Policy Frameworks on Social Inequalities among Women in the European Union: The LabourMarket Participation of Mothers." Social Politics 20(3):297-328.

Kenworthy, Lane. 1999. "Do Social-Welfare Policies Reduce Poverty? A Cross-National Assessment." Social Forces 77:1119-39. 
Korpi, Walter, and Joakim Palme. 1998. "The Paradox of Redistribution and Startegies of Equality: Welfare State Institutions, Inequality, and Poverty in Western Countries." American Sociological Review 63:661-87.

Kudva, Neema and Lourdes Beneria (eds). 2005. Rethinking Informatization: Poverty, precarious jobs, and social protection. Cornell University Open Access Repository. http://ecommons.cornell.edu/bitstream/1813/3716/1/Rethinking\%20Informalization.pdf

Lim, Linda Y.C. 1983. "Capitalism, Imperialism, and Patriarchy: The Dilemma of Third World Women Workers in Multinational Factories." in Women, Men and the International Division of Labor, edited by June Nash and Maria Patricia Fernandez Kelly. Albany, NY: SUNY Press.

Mandel, Hadas, and Moshe Semoyonov. 2006. "A Welfare State Paradox: State Interventions and Women's Employment Opportunities in 22 Countries." American Journal of Sociology 111(6):1910-49.

Mason, Andrew D. and King, Elizabeth M. 2001. Engendering development through gender equality in rights, resources, and voice. A World Bank policy research report. Washington DC ; World Bank.

http://documents.worldbank.org/curated/en/2001/01/891686/engendering-developmentthrough-gender-equality-rights-resources-voice

Mies, Maria. 1999. Patriarchy and Accumulation On A World Scale: Women in the International Division of Labour. London: Zed Books (1999).

Misra, Joya, Stephanie Moller, and Michelle J Budig. 2007. "Work-Family Policies and Poverty for Partnered and Single Women in Europe and North America." Gender \& Society 21(6):804-27.

Moller, Stephanie, Evelyne Huber, John D Stephens, David Bradley, and Francois Nielsen. 2003. "Determinants of Relative Poverty in Advanced Capitalist Democracies." American Sociological Review 68(February):22-51.

Moore, Gwen, and Gene Shackman. 1996. "Gender and Authority: A Cross-National Study." Social Science Quarterly 77(2):273-88.

Myant, Martin, and Jan Drahokoupil. 2011. Transition Economies: Political Economy in Russia, Eastern Europe and Central Asia. Hobokne, NJ: John Wiley and Sons, Inc.

Nash, June, and Maria Patricia Fernandez-Kelly. 1983. Women, Men and the International Division of Labor. Albany, NY: SUNY Press.

Noelke, Andreas and Arjan Vliegenthart. 2009. "Enlarging the Varieties of Capitalism: The Emergence of Dependent Market Economies in East Central Europe" World Politics, 61 (4): 670-702. 
Ong, Aihwa. 1987. Spirits of Resistance and Capitalist Discipline: Factory Women in Malaysia Albany NY: State University of New York Press.

Pascall, Gilian, and Anna Kwak. 2005. Gender Regimes in Transition in Central and Eastern Europe. Bristol, UK: The Policy Press.

Paxton, Pamela, Sheri Kunovich, and Melanie M. Hughes. 2007. "Gender in Politics." Annual Review of Politics 33:263-84.

Petit, Becky, and Jennifer L Hook. 2009. Gendered Tradeoffs: Family, Social Policy, and Economic Ineqiality in Twenty-One Countries. New York: Russell Sage Foundation.

Sassen, Saskia. 2003. "Global Cities and Survival Circuits" pp. 254-274 in Barbara Ehrenreich and Arlie Russell Hochschield (eds). Global Woman: Nannies, Maids and Sex Workers in the New Economy, New York: Metropolitan Books.

Seguino, Stephanie. 2000. "Gender Inequality and Economic Growth : A Cross-Country Analysis." World Development 28(7):1211-30.

Shittirak, Sinith. 1988. Daughters of Development. New York: Zed Books.

Standing, Guy. 1989. "Global feminization through flexible labor." World Development 17(7):1077-95.

Szelenyi, Ivan, and Janos Ladanyi. 2006. Patterns of Exclusion: Constructing Gypsy Ethnicity and the Making of an Underclass in Transitional Societies of Europe. New York, NY: East European Monographs.

Tinker, Irene (Ed.). 1990. Persistent Inequalities: Women and World Development. Oxford: Oxford University Press.

Tzannatos, Zafiris. Women and Labor Market Changes in the Global Economy: Growth Helps, Inequalities Hurt and Public Policy Matters. World Development, Volume 27, Number 3, March 1999, pp. 551-569(19)

Ward, Kathryn. 1993. "Re-conceptualizing World-System Theory to Include Women." Pp. 43-68 In Paula England (ed.) Theory on Gender/Feminism on Theory. Aldine.

Weiner, Elaine. 2007. Market Dreams: Gender, Class, and Capitalism in the Czech Republic. Ann Arbor: University of Michigan Press.

Wieping, Pamela, and Ineke Maas. 2005. "Gender Differences in Poverty: A CrossNational Study." European Sociological Review 21(3):187-200. 